\title{
Political Myth
}




\section{Key Concepts in Political Science GENERAL EDITOR: Leonard Schapiro eXecutive editor: Peter Calvert}

Other titles in the same series include:

ALREADY PUBLISHED

Martin Albrow

Anthony H. Birch

Brian Chapman

Peter Calvert

Ioan Davies

Joseph Frankel

Carl J. Friedrich

P. H. Partridge

John Planenatz

John C. Rees

Leonard Schapiro

Paul Wilkinson

\section{IN PREPARATION}

Shlomo Avineri

Karl Deutsch

S. E. Finer

Geoffrey Goodwin

Julius Gould

J. F. Lively

Otto Pick and

Julian Critchley
Bureaucracy

Representation

Police State

Revolution

Social Mobility and

Political Change

National Interest

Tradition and Authority

Consent and Consensus

Ideology

Equality

Totalitarianism

Social Movement
Utopianism

Legitimacy

Dictatorship

International Society

Violence

Democracy

Collective Security 


\section{Political Myth}

\section{Henry Tudor}

University of Durham 
ISBN 978-o-333-11894-8 ISBN 978-1-349-01048-6 (eBook) DOI 10.1007/978-1-349-01048-6

(C) 1972 by Pall Mall Press Ltd London First published in 1972 by Pall Mall Press Ltd

Reprint of the original edition 1972

All rights reserved. No part of this publication may be reproduced or transmitted, in any form or by any means, without permission

Published by The Macmillan Press Ltd London and Basingstoke Associated companies in New York Toronto Dublin

Melbourne Johannesburg and Madras SBN paper $333 \times 19844$ Set by Gloucester Typesetting Co. Ltd Gloucester

Not for sale in the U.S.A.

Papermacs are sold subject to the condition that they shall not, by way of trade or otherwise, be lent, re-sold, hired out, or otherwise circulated

without the publisher's prior consent in any form of binding or cover other than that in which they are published and without a similar condition including this condition being imposed on the subsequent purchaser 


\section{Contents}

\section{'Key Concepts' an Introductory Note}

\section{Preface}

\section{Chapter One}

The study of political myths

Allegorical and Euhemerist theories of myth

The Idealist theory of myth

Linguistic, aetiological and ritual theories of myth

Myth as a primitive world-view

The question of Origins

\section{Chapter Two}

Psychological theories of myth

Sociological theories of myth

The structuralist theory of myth

Myths as the expression of timeless truths

\section{Chapter Three}

The genesis of the Roman Foundation Myth

Foundation and empire

The dilemma of the Roman ruling class

Cicero's version of the Foundation Myth

The settlement of Augustus Caesar

\section{Chapter Four}

Foundation and eschatos

The Christian Myth of the Millennium

National revolutionary myths

The Myth of the Aryan Race

Marx and the demand for a morally coherent world The Myth of the Proletarian Revolution 


\section{Chapter Five}

Ideology and political myths

Political myths and practical activity

Illusion and deception in political myths

Political myth

\section{Notes and References}

\section{Bibliography}

\section{Index}




\section{'Key Concepts' an Introductory Note}

Political concepts are part of our daily speech-we abuse "bureaucracy' and praise 'democracy', welcome or recoil from 'revolution'. Emotive words such as 'equality', 'dictatorship', 'élite' or even 'power' can often, by the very passions which they raise, obscure a proper understanding of the sense in which they are, or should be, or should not be, or have been used. Confucius regarded the 'rectification of names' as the first task of government. 'If names are not correct, language will not be in accordance with the truth of things', and this in time would lead to the end of justice, to anarchy and to war. One could with some truth point out that the attempts hitherto by governments to enforce their own quaint meanings on words have not been conspicuous for their success in the advancement of justice. 'Rectification of names' there must certainly be: but most of us would prefer such rectification to take place in the free debate of the university, in the competitive arena of the pages of the book or journal.

Analysis of commonly used political terms, their reassessment or their 'rectification', is, of course, normal activity in the political science departments of our universities. The idea of this series was indeed born in the course of discussion between a few university teachers of political science, of whom Professor S. E. Finer of Manchester University was one. It occurred to us that a series of short books, discussing the 'Key Concepts' in political science would serve two purposes. In universities these books could provide the kind of brief political texts which might be of assistance to students in gaining a fuller understanding of the terms which they were constantly using. But we also hoped that outside the universities there exists a reading public which has the time, the curiosity and the inclination to pause to reflect on some of those words and ideas which are so often taken for granted. Perhaps even 'that insidious and crafty animal', as Adam Smith described the politican and statesman, will occasionally derive some pleasure or even profit from that more leisurely analysis which academic study can afford, and which a busy life in the practice of politics often denies.

It has been very far from the minds of those who have been concerned in planning and bringing into being the 'Key Concepts' series to try 


\section{0/'Key Concepts' an Introductory Note}

and impose (as if that were possible!) any uniform pattern on the authors who have contributed, or will contribute, to it. I, for one, hope that each author will, in his own individual manner, seek and find the best way of helping us to a fuller understanding of the concept which he has chosen to analyse. But whatever form the individual exposition may take, there are, I believe, three aspects of illumination which we can confidently expect from each volume in this series. First, we can look for some examination of the history of the concept, and of its evolution against a changing social and political background. I believe, as many do who are concerned with the study of political science, that it is primarily in history that the explanation must be sought for many of the perplexing problems of political analysis and judgement which beset us today. Second, there is the semantic aspect. To look in depth at a 'key concept' necessarily entails a study of the name which attached itself to it; of the different ways in which, and the different purposes for which, the name was used; of the way in which in the course of history the same name was applied to several concepts, or several names were applied to one and the same concept; and, indeed, of the changes which the same concept, or what appears to be the same concept, has undergone in the course of time. This analysis will usually require a searching examination of the relevant literature in order to assess the present stage of scholarship in each particular field. And thirdly, I hope that the reader of each volume in this series will be able to decide for himself what the proper and valid use should be of a familiar term in politics, and will gain, as it were, from each volume a sharper and better-tempered tool for political analysis.

There are many today who would disagree with Bismarck's view that politics can never be an exact science. I express no opinion on this much debated question. But all of us who are students of politics-and our numbers both inside and outside the universities continue to grow - will be the better for knowing what precisely we mean when we use a common political term. 


\section{Preface}

This is an introductory book. Its purpose is simply to draw attention to a common but neglected type of political argument, and it is aimed at the educated layman and, more particularly, at the university undergraduate. I am conscious of the fact that it reads a bit like a guided tour, but, given the purpose of this series and the nature of my topic, I could not see how else to approach the task.

In the first two chapters I expound and criticize various theories that have been put forward to explain the occurrence and character of mythical thought. The need to be brief has sometimes led me to state dogmatically points which really require elaborate qualification, and I have dismissed somewhat brusquely the doctrines of many deservedly famous men. However, although I have simplified, I have not, I think, misrepresented the positions I criticize. Great men are, in any case, fair game, and it is unlikely that their reputations will be damaged by any injustice I might unwittingly have done them.

I have devoted the whole of chapter three to a study of the Roman Foundation Myth partly because it has exercised so enduring an influence on Western political thought and partly because it is the 'purest' example of a political myth I could find. Chapter four deals with a number of more recent political myths which, in contrast to foundation myths, I have described as eschatological or revolutionary myths. It goes without saying that each one of them could (and indeed should) have been subjected to at least as detailed a treatment as the Roman Foundation Myth; but space did not permit. The fifth and final chapter raises, though it does not resolve, several questions concerning the relationship of political myth to practical experience.

I have, wherever possible, used recent and easily available editions. Except where indicated, translations from works in foreign languages are my own. All quotations from classical authors are taken from the Loeb Classical Library editions. 


\section{2/Preface}

My intellectual debts are many, and I will not attempt to acknowledge them. I must, however, thank Professor Schapiro for his helpful editorial suggestions, Mr Bernard Mullins of the Pall Mall Press for his patient encouragement, and Mrs E. Manning and Mrs C. Bates for performing so cheerfully the hideously boring task of typing up my manuscript. 